\title{
Evaluating the production efficiency, purity and chemical compounds of the Vicia ervilia protein isolates produced by different methods of extraction
}

\author{
Masoom Hatamikia $^{1}$, Saber Abbaszadeh ${ }^{2,3}$, Amir Hossein Elhamirad $^{4^{*} \mathbb{D}}$, Elham Azarpazhooh , Parvin Sharayei $^{5}$ \\ ${ }^{1}$ Deputy for Food and Drug, Lorestan University of Medical Sciences, Khorramabad, Iran \\ ${ }^{2}$ Student Research Committee, Lorestan University of Medical Sciences, Khorramabad, Iran \\ ${ }^{3}$ Razi Herbal Medicines Research Center, Lorestan University of Medical Sciences, Khorramabad, Iran \\ ${ }^{4}$ Department of Food Science \& Technology, Sabzevar Branch, Islamic Azad University, Sabzevar, Iran \\ ${ }^{5}$ Agricultural Engineering Research Department, Khorasan Razavi Agricultural and Natural Resources Research and Education Center, AREEO, \\ Mashhad, Iran
}

\section{ART I CLE INFO}

\section{Article Type:}

Original Article

\section{Article History:}

Received: 16 May 2019

Accepted: 22 June 2019

\section{Keywords:}

Vicia ervilia

Medicinal plant

Compounds

Extraction methods

\begin{abstract}
A B S T R A C T
Introduction: Vicia ervilia, known as bitter vetch is an ancient grain legume crop from Poaceae family. Due to its low cost and production capability in Iran and having high protein content, the resulted flour and its protein products can be evaluated in terms of usability in the food industry. This study was aimed to evaluate the production efficiency, purity and chemical compounds of the V. ervilia protein isolates produced by different methods of alkali and acid extraction-sedimentation at isoelectric point, dialysis -salt extraction and miscella sedimentation

Methods: In this study, V. ervilia was provided from the Agricultural Jihad Organization of Lorestan province and the protein isolates of $V$. ervilia were produced using different methods of protein extraction such as Acidic extraction-sedimentation at isoelectric point, Alkaline extraction-sedimentation at the isoelectric point, dialysis-salt extraction and extraction by miscella sedimentation.

Results: The results showed that saline extraction methods (salt-dialysis and miscella) were significantly more effective than the isoelectric sedimentation methods (alkaline and acidic) on increasing the efficiency, purity and protein content of isolates and decreasing the impurities and carbohydrates.

Conclusion: The results of this research show that the salt extraction methods (salt-dialysis and miscella) are significantly more effective in increasing the efficiency, purity and protein rate of isolates and in decreasing impurities and carbohydrates than the isoelectric sedimentation methods (alkaline and acidic).
\end{abstract}

Implication for health policy/practice/research/medical education:

In general, it can be said that the cold extraction methods of protein (salt-dialysis and miscella sedimentation) prevent the denaturation of proteins better than the methods based on sedimentation at the isoelectric point (alkaline and acidic method). The low denaturation of proteins causes less change in the conformation and structure of proteins, and thus the extracted proteins are more in original and natural state (not denatured).

Please cite this paper as: Hatamikia M, Elhamirad AH, Heydari R, Sharayei P, Azarpazhooh E. Evaluating the production efficiency, purity and chemical compounds of the Vicia ervilia protein isolates produced by different methods of extraction. J Herbmed Pharmacol. 2019;8(4):314-319. doi: 10.15171/jhp.2019.46.

\section{Introduction}

Cereals are from Fabaceae (Leguminous) family having 16000 to 19000 species and almost 750 genera. They are considered as one of the most important plant sources rich in protein that can provide a valuable nutritional bio-compound in combination with grains because of having the considerable amounts of high-quality protein (17\% to $38 \%)$. The raw protein rate of cereal seeds $(18 \%$ to $50 \%)$ is two to three times the grain seeds ( $10 \%$ to $15 \%)$. Therefore, cereal can be used as a source rich in 
protein in producing plant protein products as flour ( $50 \%$ to $65 \%$ protein), concentrate $(65 \%$ to $90 \%$ protein), or protein isolate (more than $90 \%$ protein) (1). Trying to find out alternative and cheap sources of protein for human nutrition has led to conduct different researches on using some of the less known cereals in the developing countries (2). The reason for these extensive researches is the abundance and low cost of cereals as a potential source of protein for the people of these countries who have less ability to supply protein from the livestock sources (3). Vicia ervilia (with the common name of Bitter Vetch) is a seed of plant that (when is broken) looks like a red lentil. (4). Considering the ability to produce this product in Iran and high protein content in this seed, its resulted flours and its protein products can be evaluated in respect of functional characteristics and usability in the food industry (5). An approximate analysis of $V$. ervilia shows that its chemical composition is almost similar to cereals. Based on the studies conducted on V. ervilia, it has been specified that carbohydrates constitute a large part of it. Protein, fat, fiber, minerals (potassium, phosphorus, copper, iron, calcium) and vitamins are other constituents of V. ervilia (6). Vicia ervilia, known as bitter vetch is an ancient grain legume crop from Poaceae family. Due to its low cost and production capability in Iran and having high protein content, the resulted flour and its protein products can be evaluated in terms of usability in the food industry. This study was aimed to evaluate the production efficiency, purity and chemical compounds content of the Vicia ervilia protein isolates produced by different methods of alkali and acid extraction-sedimentation at isoelectric point, dialysis -salt extraction and miscella sedimentation

\section{Materials and Methods}

The technology and methods used to extract protein from Vicia ervilia

One of the advantages of using the technique of sediment based on the isoelectric point is that this method can effectively eliminate some anti-nutritional components (7). The process of producing the protein isolate using the method of alkaline extraction-sediment at the isoelectric point includes water extracting of soluble proteins from flour or meal, separating the insoluble residues from the water phase, sedimentation protein at the isoelectric point (protein clot formation), separating the protein clot from the water phase, washing and drying. Extracting using salt produces an isolate that contains both globulins and albumens (8-10). Extracting by miscella sediment usually results in forming a protein isolate that is in the form of miscella and is fixed by hydrogen bands (11) and includes both albumin and globulin proteins and has less denatured and damaged proteins than the method of sediment at the isoelectric point (12).

\section{Preparing the fatless flour of Vicia ervilia}

In this study, V. ervilia was provided from the Agricultural Jihad Organization of Lorestan province. Then, they were milled by a laboratory mill. For uniformity of the resulted flour particles, the milled flour was sifted by screen of $1 \mathrm{~mm}$, and maintained at the refrigerator temperature until being used. In order to prepare the fatless flour of $V$. ervilia, the fat of the resulted screened and uniformed flour with a ratio of 1: 3 of weight-volume removed using the normal hexane-solvent. So, in order to remove the fat completely, the mixture was placed on a magnetic mixing with rotation of $500 \mathrm{rpm}$ for 40 minutes. This process was repeated twice to extract the oil completely. For smoothing and separating the normal hexane solvent, Whatman filter paper was used and then placed under hood for 18 hours to dry and separate the normal hexane completely, and finally the fatless flour of $V$. ervilia was maintained in closed containers in a refrigerator at $4^{\circ} \mathrm{C}$, for the next stages of producing the protein isolates by different methods of protein extraction $(13,14)$.

Producing the protein isolates of $V$. ervilia using different methods of protein extraction

\section{Acidic extraction-sedimentation at isoelectric point}

One-hundred grams of fatless flour of $V$. ervilia with weight-volume of 1:15 ratio was mixed with de-ionized water. Then, its $\mathrm{pH}$ was reached at 2.5 by hydrochloric acid 1 normal. The mixture (suspension) was placed on the magnetic mixing with rotation of $500 \mathrm{rpm}$ at the room temperature for 1 hour so that the protein became completely soluble and separated from non-protein compounds. Then, the mixture was centrifuged at $4^{\circ} \mathrm{C}$ for 20 minutes in $4500 \mathrm{~g}$. Finally, the supernatant was collected. The resulted refuse was re-suspended by deionized water with a weight-volume ratio of $1: 5$, and its $\mathrm{pH}$ was set again at $\mathrm{pH}=2.5$ with hydrochloric acid 1 molar, and stirred at the room temperature for 45 minutes and finally re-centrifuged under the same conditions. The two supernatants resulted from centrifuging were mixed and their $\mathrm{pH}$ was set at 5.4 (isoelectric point and protein sedimentation) by sodium hydroxide 1 normal. Then, the mixture was centrifuged again in $4500 \mathrm{~g}$ at $4^{\circ} \mathrm{C}$ for 20 minutes to recover the sediment proteins. The clear supernatant was discarded and the resulted sediment protein was collected. For higher purity, the recovered protein was washed in five steps and at each step for 5 minutes by centrifugation at $4500 \mathrm{~g}$ and with de-ionized water to set its $\mathrm{pH}$ at about 7 . The resulted protein isolate was maintained in the closed containers at $-30^{\circ} \mathrm{C}$ and then dried by freeze dryer $(15,16)$.

Alkaline extraction-sedimentation at the isoelectric point This method was similar to the acidic extractionsedimentation at isoelectric point method with very 
slight variations $(13,14)$. In the acidic method, the $\mathrm{pH}$ was adjusted to 2.5 with $\mathrm{HCl}$ (one normal) and in alkaline method, the $\mathrm{pH}$ was adjusted to 11 with sodium hydroxide (one normal).

\section{Dialysis-salt extraction}

One-hundred grams of fatless flour of $V$. ervilia with weight-volume 1:10 ratio was mixed with sodium phosphate buffer 0.1 molar (its $\mathrm{pH}$ should be set at 8) which contained $6.4 \%$ aqueous solution of potassium chloride. Then, the mixture was stirred on the magnetic mixing with rotation of $500 \mathrm{rpm}$ at the room temperature for 24 hours and finally was centrifuged at $4^{\circ} \mathrm{C}$ for 20 minutes in $4500 \mathrm{~g}$ by a centrifuge having fridge. The supernatant was collected and dialyzed opposite the de-ionized water at $4^{\circ} \mathrm{C}$ and with 6-8 $\mathrm{kDa}$. The de-ionized water was renewed three times a day with fresh de-ionized water. Dialysis was performed for 72 hours until the direction of dialysis water (the used de-ionized water) reached at about 20 microsiemens per $\mathrm{cm}(\mu \mathrm{S} / \mathrm{cm})$ (equivalent to $2-2.5 \mathrm{mS} /$ $\mathrm{cm}$ ). After dialysis, the dialyzed was maintained in closed containers at $-30^{\circ} \mathrm{C}$ until it was freeze dried $(13,14)$.

Extraction by miscella sedimentation

One-hundred grams of fatless flour of $V$. ervilia in 1 normal solution of chloride sodium with weight-volume 1:10 ratio was mixed and stirred by the magnetic mixing with rotation of $500 \mathrm{rpm}$ at the room temperature for 2 hours. Then, it was centrifuged at $4^{\circ} \mathrm{C}$ for 20 minutes in $4000 \mathrm{~g}$ by a centrifuge having fridge. The supernatant was collected and diluted ten times by cold de-ionized water $\left(4^{\circ} \mathrm{C}\right)$ and placed at $4^{\circ} \mathrm{C}$ for 18 hours. Then again, the solution was centrifuged at $4^{\circ} \mathrm{C}$ for 20 minutes in $4000 \mathrm{~g}$. After centrifugation, the resulted sediment was collected and maintained in closed containers at $-30^{\circ} \mathrm{C}$ and then dried by freeze drier.

Test methods

The efficiency rate and production efficiency of the sedimentary protein isolate (in terms of the weight of the obtained sedimentary isolate) were calculated based on the formula (production yield $=$ weight of sedimentary protein. used flour weight $\times 100)(17)$. Total ash rate was evaluated using an electric furnace at $550^{\circ} \mathrm{C}$ (Thermolyne F6000 Barnstead, Germany) and the raw fiber rate was measured using a single fiber machine (Foss, Swede). The carbohydrates were evaluated through Line and Ainon using Fehling solutions and the fat rate was measured using a digital Soxhlet apparatus (Buchi, Swiss). The protein rate was evaluated using a macro Kjeldahl apparatus (Buchi, Swiss).

\section{Statistical analysis}

All protein extraction methods from $V$. ervilia and experiments were performed in three repetitions, and the resultswerepresented asthemeans of thesethreerepetitions. In this research, examining the effect of different treatments of protein extraction from $V$. ervilia on the production efficiency, purity and chemical compounds' content in the protein isolates were performed in three repetitions in terms of a completely randomized statistical design. The results were analyzed using SPSS software.

\section{Results}

The percentage of $V$. ervilia flour components such as protein, fat, carbohydrate, moisture, ash and raw fiber based on dry weight in this study is presented in Table 1. As seen in Table 1, the fat rate in V. ervilia flour was

Table 1. The percentage components of Vicia ervilia flour based on dry weight

\begin{tabular}{llllll}
\hline Protein & Fat & Carbohydrate & Moisture & Ash & Raw fiber \\
\hline $25.36 \pm 0.25$ & $4.50 \pm 0.2$ & $52.56 \pm 0.3$ & $6.30 \pm 0.2$ & $3.64 \pm 0.19$ & $6.83 \pm 0.12$ \\
\hline
\end{tabular}

Table 2. The effect of the different methods of extracting protein from Vicia ervilia on the content (percentage) of chemical compositions in the protein isolates $(100 \mathrm{~g})$

\begin{tabular}{|c|c|c|c|c|c|c|c|}
\hline Protein extraction method & $\begin{array}{l}\text { Production efficacy of } \\
\text { sedimentary isolate }\end{array}$ & $\begin{array}{l}\text { Purity of } \\
\text { isolate }\end{array}$ & Protein & Fat & Carbohydrate & Moisture & Ash \\
\hline $\begin{array}{l}\text { Unprocessed Vicia ervilia } \\
\text { (control) }\end{array}$ & - & - & $25.36 \pm 0.25^{e}$ & $4.50 \pm 0.2^{\mathrm{a}}$ & $59.56 \pm 0.3^{a}$ & $6.30 \pm 0.2^{\mathrm{a}}$ & $3.64 \pm 0.19^{a}$ \\
\hline Dialysis-salt method & $19.95 \pm 0.46^{a}$ & $96.92 \pm 0.0^{\mathrm{a}}$ & $96.92 \pm 0.06^{a}$ & $1.13 \pm 0.01^{\mathrm{b}}$ & $0.54 \pm 0.01^{\mathrm{e}}$ & $4.65 \pm 2.5^{b}$ & $4.25 \pm 1.5^{\mathrm{a}}$ \\
\hline Miscella sedimentation method & $17.82 \pm 0.54^{b}$ & $94.63 \pm 0.1^{\mathrm{b}}$ & $94.63 \pm 0.18^{b}$ & $1.01 \pm 0.02^{c}$ & $1.07 \pm 0.04^{d}$ & $4.47 \pm 2.5^{b}$ & $4.03 \pm 1.5^{\mathrm{a}}$ \\
\hline $\begin{array}{l}\text { Acidic method-sedimentation } \\
\text { at the isoelectric point }\end{array}$ & $13.91 \pm 0.48^{c}$ & $92.43 \pm 0.21^{c}$ & $92.43 \pm 0.21^{c}$ & $0.67 \pm 0.01^{d}$ & $4.35 \pm 0.12^{c}$ & $4.32 \pm 2.5^{b}$ & $3.79 \pm 1.5^{a}$ \\
\hline $\begin{array}{l}\text { Alkaline method- sedimentation } \\
\text { at the isoelectric point }\end{array}$ & $11.38 \pm 0.43^{d}$ & $89.33 \pm 0.1^{\mathrm{d}}$ & $89.33 \pm 0.1^{\mathrm{d}}$ & $0.4 \pm 0.01^{\mathrm{e}}$ & $8.58 \pm 0.15^{b}$ & $4.18 \pm 2.5^{b}$ & $3.87 \pm 1.5^{\mathrm{a}}$ \\
\hline
\end{tabular}

The numbers with at least one identical letter are not statistically significant $(P<0.05)$. 
$4.5 \pm 0.2 \%$ and the protein ranged from $21 \%$ to $28.52 \%$. The effect of the different methods of extracting protein from $V$. ervilia on the content of compositions in the protein isolates $(100 \mathrm{~g})$ is indicated on Table 2.

As it can be seen in Table 2, the efficiency rate of producing sedimentary protein isolates of saline extraction methods, for dialysis-salt method was $19.95 \pm 0.46 \%$ and for miscella sedimentation was $17.82 \pm 0.54 \%$ and of isoelectric sedimentation methods, for acidic method was $13.91 \pm 0.48 \%$ and for alkaline method was $11.38 \pm 0.43 \%$.

The effect of extracting protein method from $V$. ervilia on the purity rate of protein isolates was significant at level 5\% $(P<0.05)$. All the extraction methods produced isolates with a completely different purity percentage. As seen in Table 3, the purity rate of isolates for the methods of salt-dialysis was $96.92 \pm 0.06 \%$, for miscella sedimentation was $94.63 \pm 0.18 \%$, for acidic method $92.43 \pm 0.21 \%$ and for alkaline method $89.33 \pm 0.1 \%$. Generally, in this study, the least and the highest purity percentages were related to the isolate produced by the alkaline method $(89.33 \pm$ $0.1 \%)$ and the isolate produced by the salt-dialysis method $(96.92 \pm 0.06 \%)$, respectively.

The approximate composition of the flour of $V$. ervilia and protein isolates are shown in Table 2. In order to produce isolates, the fat of $V$. ervilia flour was removed by $\mathrm{N}$-hexane solvent. All four methods of protein extraction reduced carbohydrates rate in the protein isolates compared to the control ( $V$. ervilia flour), significantly.

\section{Discussion}

The protein rate- of V. ervilia flour in this study was lower than the protein percentage in the flour of chickpea, lentils and kidney beans (18) and higher than Sudanic beans or peas (19). The reported rate of fat for V. ervilia in this study is less than the reported rate by Taghizadeh et al (20) and higher than the reported rates by Yar Ahmadi et al (21) and Arabi (23). Also, the fat rate of V. ervilia is less than that of soy and chickpea (18) and higher than peas and Sudanic beans (19). The fiber rate of V. ervilia has been reported as $7.7 \%$ that is higher than the fiber rate reported in this study. Other researchers have reported fewer quantities of fiber than the fiber rate of $V$. ervilia in this study that are mentioned in Table 2. Also, the moisture rate of $V$. ervilia flour in this study was less than the moisture rate of the flour of soya, lentils and kidney beans (18) and higher than the moisture rate in the flours of chickpea and soya (18) and in accordance with the flour of broad beans, lentils, soya and peas (14). The difference in the compounds rate of $V$. ervilia compared to other studies can be attributed to the effect of some climatic and soil conditions and genetic differences.

The results of this research showed that the saline extraction methods (salt-dialysis and miscella) were more effective in increasing the isolates efficacy than the isoelectric sedimentation methods. Generally in this study, the lowest and the highest efficacy rates of sedimentary isolates were related to the isolates produced by alkaline method $(11.38 \pm 0.43 \%)$ and the isolate produced by the dialysis-salt method $(19.95 \pm 0.46 \%)$, respectively. The fundamental proteins in the legumes were globulins and albumins. Globulins constitute about $70 \%$ of the protein of legumes including $V$. ervilia. Globulins are soluble in neutral saline solutions and are almost insoluble in water and have the minimum solubility in a $\mathrm{pH}$ between 4 and 5 (isoelectric point) (24). Based on studies, it has been reported that the isolates produced by isoelectric sedimentation methods are richer with globulins because of the higher sedimentation of globulin proteins (25), while the products of salt extraction are usually a mixture of globulins and albumins (10). It seems that one of the reasons for the higher efficacy rate of sedimentary isolates in saline extraction methods than isoelectric sedimentation methods is the extraction of albumin proteins in addition to globulin proteins. It has been reported that the isoelectric sedimentation methods are more effective than the miscella formation method in increasing the sedimentary isolate efficiency rate for safflower (11), Voandzeia subterranea and soya (26) that are not consistent with the results of this study. It seems that the lack of optimization in the method of producing the isolates in these studies is due to the less recovery and efficiency of sedimentary protein isolates in saline extraction methods than the isoelectric sedimentation methods. For example, a study found that the percentage of the protein extracted from safflower by miscella method could be increased from $44.2 \%$ to more than 65 percent of time to optimize the isolate producing method and increase the $\mathrm{NaCl}$ concentration from $0.2 \mathrm{M}$ to $1.2 \mathrm{M}$ (11). The efficacy content of isolates in the alkali-sedimentation extraction method at the isoelectric point varies from 9 percent for bean and 16 percent for chickpea (13). In other studies, the efficiency rates of sedimentary protein isolates of the chickpea produced by different methods of acidic extraction, salt-dialysis, and miscella have been reported as $10 \%(15), 19.2 \%$ and $7.6 \%$ (13), respectively that are consistent with the results of this study.

One of the reasons for producing protein isolates is removing impurities and increasing the purity and achieving pure protein. In general, the isolate producing process involves the aqueous extracting of the soluble proteins from flour or bulgur, separating the insoluble residues from the aqueous phase, sedimentation of protein at the isoelectric point (forming protein clot), separating the protein clot from the aqueous phase, washing and drying $(8,27)$. One of the reasons for the lower purity of alkali isolate than other methods is the changes resulted from the high denaturation in the alkaline method and possibly higher exclusion of non-protein materials such 
as carbohydrates and fiber from $V$. ervilia (raw material) during the protein extraction process and remaining of these compounds in isolate and as a result, reduction of the purity of the produced isolate. According to high denaturation in the alkali method due to the use of high $\mathrm{pH}$, the possibility of non-protein materials exclusion from the raw material in this method is higher than the acidic method (28). This issue can be a reason for the low purity of isolate and the high impurities (saccharides, soluble sugars, carbohydrates and fiber) in alkaline extraction method compared to acidic method. One of the reasons that the isolates produced by salt extraction method might be higher purity and less impurity than the isoelectric sedimentation methods is the low denaturation of proteins in these isolates. In general, it can be said that the cold protein extraction methods (salt-dialysis and miscella sedimentation) compared to the methods based on the isoelectric point sedimentation technique (alkaline and acidic method) prevent the denaturation of proteins.

The cold extraction methods of protein (salt - dialysis extraction, and miscella sedimentation) prevent the denaturation of proteins compared to the methods based on sedimentation at isoelectric point (alkaline and acidic). The highest rate of carbohydrates reduction in protein isolates is observed in the methods of salt-dialysis, miscella, acidic and alkali extractions, respectively. One of the reasons of higher rate of carbohydrates in the isolate produced by alkaline method than other methods is the changes resulted from denaturation in the alkaline method and possibly higher non-protein matters exclusion such as carbohydrates and fiber from $V$. ervilia (row matter) during the protein extraction process and remaining of these compounds in the isolate (28).

In the salt extraction method, various concentrations of salt are used to dissolve the proteins of $V$. ervilia by removing salt during dialysis, while the hydrated layers (hydration) around the protein surface are disintegrated (29). In this research, the results showed that for extracting the proteins of V.ervilia, the salt extraction method (saltdialysis and miscella) was more effective than other methods (isoelectric sedimentation), and resulted in a higher concentration of protein in the isolate.

From the nutritional point of view, producing the isolates of salt extraction is preferred to produce the isolates of acidic and alkaline extraction because of the injuries to some nutrient compounds in the alkaline and acidic conditions; because the vitamins of group B, especially thiamine and riboflavin, degrade slowly under the alkaline conditions and at the ambient temperature (30).

\section{Conclusion}

The results of this research show that the salt extraction methods (salt-dialysis and miscella) were significantly more effective on increasing the efficiency, purity and protein rate of isolates and decreasing impurities and carbohydrates than the isoelectric sedimentation methods (alkaline and acidic). Also, low fat rate in the alkaline isolate is probably due to the denaturation intensity created in this isolate and as a result, more exclusion of fat during the protein extraction process. In general, it can be said that the cold extraction methods of protein prevent the denaturation of proteins compared to the methods based on sedimentation at the isoelectric point. The low denaturation of proteins causes less change in the conformation and structure of proteins, and thus the extracted proteins are in their more original and natural state (not denatured).

\section{Acknowledgment}

We are grateful to Lorestan Food and Drug control lab for helpful technical assistance.

\section{Authors' contributions}

$\mathrm{MH}$ designed and analyzed the data and revised the manuscript. MH, AHE, RH, PSH and EA were responsible for performing the experimental work. The paper was read and approved by all authors for publication.

\section{Conflict of interests}

The authors declare no conflict of interest.

\section{Ethical considerations}

There is no particular ethical case in this study

\section{Funding/Support}

None.

\section{References}

1. Boye J, Zare F, Pletch A. Pulse proteins: Processing, characterization, functional properties and applications in food and feed. Food Res Int. 2010;43(2):414-31. doi: 10.1016/j.foodres.2009.09.003.

2. Chau CF, Cheung PCK. Functional properties of flours prepared from three Chinese indigenous legume seeds. Food Chem. 1998;61(4):429-33. doi: 10.1016/S03088146(97)00091-5.

3. Vadivel V, Janardhanan K. Nutritional and anti-nutritional attributes of the under-utilized legume, Cassia floribunda Cav. Food Chem. 2001;73(2):209-15. doi: 10.1016/S03088146(00)00280-6.

4. Haddad SG. Bitter vetch grains as a substitute for soybean meal for growing lambs. Livest Sci. 2006;99(2-3):221-5.

5. Belido L. Grain legumes for animal feed. https://hort. purdue.edu/newcrop/1492/legume_animal.html. 1994.

6. Ozcan T. Total protein and amino acid compositions in the acorns of Turkish Quercus L. taxa. Genet Resour Crop Evol. 2006;53(2):419-29. doi: 10.1007/s10722-004-1337-7.

7. Mondor M, Aksay S, Drolet H, Roufik S, Farnworth E, Boye JI. Influence of processing on composition and 
antinutritional factors of chickpea protein concentrates produced by isoelectric precipitation and ultrafiltration. Innov Food Sci Emerg Technol. 2009;10(3):342-7. doi: 10.1016/j.ifset.2009.01.007.

8. Fallah S, Rostaei M, Lorigooini Z, Abbasi Surki A. Chemical compositions of essential oil and antioxidant activity of dragonhead (Dracocephalum moldavica) in sole crop and dragonhead- soybean (Glycine max) intercropping system under organic manure and chemical fertilizers. Ind Crops Prod. 2018;115:158-65. doi: 10.1016/j.indcrop.2018.02.003.

9. Ghasemi S, Lorigooini Z, Wibowo J, Amini-Khoei H. Tricin isolated from Allium atroviolaceum potentiated the effect of docetaxel on PC3 cell proliferation: role of miR-21. Nat Prod Res. 2019;33(12):1828-31. doi: 10.1080/14786419.2018.1437439.

10. Liu LH, Hung TV, Bennett L. Extraction and characterization of chickpea (Cicer arietinum) albumin and globulin. J Food Sci. 2008;73(5):C299-305. doi: 10.1111/j.17503841.2008.00773.x.

11. Paredes-Lopez O, Ordorica-Falomir C, Olivares-Vazquez MR. Chickpea protein isolates: physicochemical, functional and nutritional characterization. J Food Sci. 1991;56(3):7269. doi: 10.1111/j.1365-2621.1991.tb05367.x.

12. Cordero-de-los-Santos MY, Osuna-Castro JA, Borodanenko A, Paredes-Lopez O. Physicochemical and functional characterisation of amaranth (Amaranthus hypochondriacus) protein isolates obtained by isoelectric precipitation and micellisation. Food Sci Technol Int. 2005;11(4):269-80. doi: 10.1177/1082013205056491.

13. Stone AK, Karalash A, Tyler RT, Warkentin TD, Nickerson MT. Functional attributes of pea protein isolates prepared using different extraction methods and cultivars. Food Res Int. 2015;76:31-8. doi: 10.1016/j.foodres.2014.11.017.

14. Karaca AC, Low N, Nickerson M. Emulsifying properties of chickpea, faba bean, lentil and pea proteins produced by isoelectric precipitation and salt extraction. Food Res Int. 2011;44(9):2742-50. doi: 10.1016/j.foodres.2011.06.012.

15. Bakhshi Moghaddam F, Milani A, Mortazavi SA, Meshkani SM. Effect of extraction methods on functional properties of chickpea protein isolated. Iranian Journal of Food Science and Technology. 2013;10(38):11-20. [Persian].

16. Hosseinzadeh Samani B, Lorigooini Z, Rostami S, Zareiforoush $\mathrm{H}$, Behruzian $\mathrm{M}$, Behruzian A. The simultaneous effect of electromagnetic and ultrasound treatments on Escherichia coli count in red grape juice. J Herbmed Pharmacol. 2018;7(1):29-36. doi: 10.15171/ jhp.2018.06.

17. Cruz-Solorio A, Villanueva-Arce R, Garín-Aguilar ME, Leal-Lara H, Valencia-Del Toro G. Functional properties of flours and protein concentrates of 3 strains of the edible mushroom Pleurotus ostreatus. J Food Sci Technol. 2018;55(10):3892-3901. doi: 10.1007/s13197-018-3312-x.

18. Assadpour E, Jafari SM, Sadeghi Mahoonak A, Ghorbani M. Evaluation of emulsifying and foaming capacity of the legume flours and the influence of ph and ionic strength on these properties. Iranian Food Science and Technology Research Journal. 2011;7(1):80-91. [Persian].
19. Kaur M, Singh N. Characterization of protein isolates from different Indian chickpea (Cicer arietinum L.) cultivars. Food Chem. 2007;102(1):366-74. doi: 10.1016/j. foodchem.2006.05.029.

20. Taghizadeh M, Shokrollahi B, Hamedi F. Evaluating the physicochemical and mechanical properties of bittervetch seed (Vicia ervilia) and the functional properties of the resulted flour. Iranian Food Science and Technology Research Journal. 2017;13(1):38-52. [Persian].

21. Yar Ahmadi B, Ghorbani K, Moayedinezhad A, Mohammad Taghi M. Evaluation of determining nutritional value and chemical composition of Vicia ervilia, Vicia villosa Roth and lathyrus available in Lorestan province. The second seminar on livestock and poultry nutrition research of Iran; 2009;197-202.

22. Arabi AS. Determination of the nutritional value of grain and forage of Vicia ervilia in Hamadan province [thesis]. Tehran: Department of Animal Sciences, Tehran Agriculture Faculty; 1997. [Persian].

23. Sadeghi G, Pourreza J, Samei A, Rahmani H. Chemical composition and some anti-nutrient content of raw and processed bitter vetch (Vicia ervilia) seed for use as feeding stuff in poultry diet. Trop Anim Health Prod. 2009;41(1):8593. doi: 10.1007/s11250-008-9159-9.

24. Aletor VA, Goodchild AV, Abd El Moneam AM. Nutritional and antinutritional characteristics of selected Vicia genotypes. Anim Feed Sci Technol. 1994;47(1-2):125-39. doi: 10.1016/0377-8401(94)90165-1.

25. Papalamprou EM, Doxastakis GI, Biliaderis CG, Kiosseoglou V. Influence of preparation methods on physicochemical and gelation properties of chickpea protein isolates. Food Hydrocoll. 2009;23(2):337-43. doi: 10.1016/j.foodhyd.2008.03.006.

26. Adebowale KO, Lawal OS. Comparative study of the functional properties of bambarra groundnut (Voandzeia subterranean), jack bean (Canavalia ensiformis) and mucuna bean (Mucuna pruriens) flours. Food Res Int. 2004;37(4):355-65. doi: 10.1016/j.foodres.2004.01.009.

27. Alibhai Z, Mondor M, Moresoli C, Ippersiel D, Lamarche F. Production of soy protein concentrates/isolates: traditional and membrane technologies. Desalination. 2006;191(13):351-8. doi: 10.1016/j.desal.2005.05.026.

28. Ravaghi M, Mazaheri Tehrani M, Asoodeh A. Evaluation of functional properties of four soy flours produced in Iran. Iranian Food Science and Technology Research Journal. 2010;6(3):223-8. [Persian].

29. Aluko RE, Yada RY. Structure-function relationships of cowpea (Vigna unguiculata) globulin isolate: influence of $\mathrm{pH}$ and $\mathrm{NaCl}$ on physicochemical and functional properties. Food Chem. 1995;53(3):259-65. doi: 10.1016/03088146(95)93931-G.

30. Shimelis EA, Rakshit SK. Effect of processing on antinutrients and in vitro protein digestibility of kidney bean (Phaseolus vulgaris L.) varieties grown in East Africa. Food Chem. 2007;103(1):161-72. doi: 10.1016/j. foodchem.2006.08.005. 